\title{
NEW RECORD OF LEUCORRHINIA PECTORALIS (CHAR- PENTIER, 1825) (INSECTA: LIBELLULIDAE) IN THE REPUBLIC OF MOLDOVA
}

\author{
Galina Bușmachiu \\ Institue of Zoology, Chisinau, Republic of Moldova, e-mail: bushmakiu@yahoo.com
}

\begin{abstract}
The paper includes new record of rare and protected species of Odonata - Leucorrhinia pectoralis in the Republic of Moldova. The species was cited firstly in 2009 from the Cioburciu village. In June, 2021 one adult male was identified on the palustral vegetation in the Plaiul Fagului Reserve. This is the second record of this species in the Republic of Moldova.
\end{abstract}

\section{Introduction}

The first papers dedicated to the diversity of dragonfly species in the Republic of Moldova were published at the beginning of the 20th century $[2,3]$. The dragonflies are relatively large, intensely colored insects and attract people's eyes. Several species of Odonata are protected by law both locally and internationally. One of such species is Leucorrhinia pectoralis (Charpentier, 1825), a dragonfly species from the family Libellulidae, extremely rare on the territory of the Republic of Moldova. Until now, the species has been cited from the southern region of the Republic of Moldova along the bank of Dniester River [5, 8, 9]. Some Odonata species identified in the Plaiul Fagului Reserve were cited previously [1], but does not include the newly identified species.

\section{Material and methods}

The Plaiul Fagului Reserve is situated in the North - West of the Central Moldavian plateau, $70 \mathrm{~km}$ away from Chisinau, at approximately $47^{\circ} 17^{\prime} 28^{\prime \prime} \mathrm{N} 28^{\circ} 3^{\prime} 16^{\prime \prime} \mathrm{E}$ in the Central Region of the Republic of Moldova. This reserve is an important part of the Moldavian protected areas with a total surface of $5,558.7 \mathrm{~km} 2$. Many rare species of plants, vertebrate and invertebrate animals are mentioned here, including some Carpathian elements. On the territory of the reserve there are several lakes with an area of 24 ha and 7 ha of swamps (fig.1) [7].

In summer of 2021, several field trips were made to collect entomological materials. In order to identify the species of dragonflies from the Plaiul Fagului Reserve, the specimens of Odonata were collected around the lakes and the photos of the large species were captured.

\section{Results and discussions}

As a result of investigation, new data about the species diversity of the order Odonata from the Plaiul Fagului Reserve were obtained.

Among the species identified in the Plaiul Fagului Reserve one species - Leucorrhinia pectoralis is the most interesting. The male of this species was photographed on 24 June 2021 on the palustral vegetation on the water of lake, at about 5 meters from the water edge (fig. 1b). For the first time on the territory of the Republic of Moldova Leucorrhinia pectoralis was 
found near the border of the forest and swampy meander, downstream from the Cioburciu village (Stefan-Vodă District) on 24 Mai 2009 [5] and then cited from Lower Dniester Region in "Grădina Turcească" and Olănești-Crocmaz Valley without any data of collection [8, 9].

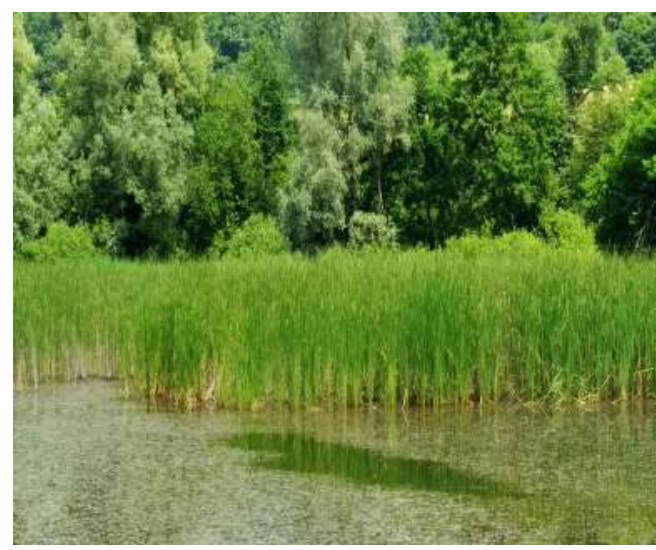

Figure 1. a - Lake in the Plaiul Fagului Reserve

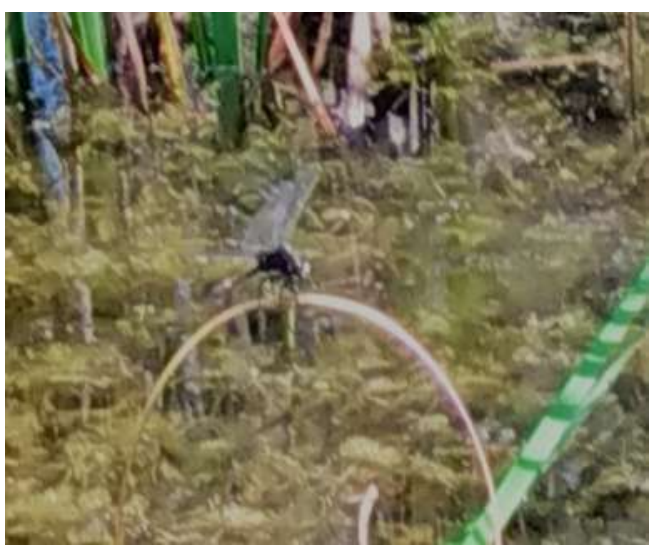

b - male of Leucorrhinia pectoralis

According to the Red Book of the Republic of Moldova Leucorrhinia pectoralis is a critically endangered species, which lives in the southern part of Moldova, especially in the Lower Dniester Region [4]. The species prefers mesotrophic freshwater basin, isolated ponds in the forest and swamps.

In the summer of 2014, after fifty years, Leucorrhinia pectoralis was rediscovered in Romania. Two males of this species were registered in the "Tinovul Mare Poiana Stampei", Succeava country [6].In Ukraine the species is regularly observed in the Volynska, Zhytomyrska, Kharkivska, Dnipropetrovska, Kyivska and other regions [10].At international level the species Leucorrhinia pectoralis is protected and included in the Bern Convention (Appendix II), the Habitats Directive (Council Directive 92/43/EEC) (Annexes II and IV), the IUCN European Red List of Dragonflies, the IUCN Red List of Mediterranean Dragonflies and in the Red List of Dragonflies of the Carpathians [6].

\section{Conclusions}

In spite of investigation carried out in the Plaiul Fagului Reserve during long time, new insect species can be still identified. The presence of the rare and protected at European and local level species, such as Leucorrhinia pectoralis, indicate the importance and conservation value of a wide range of habitats that exist in the Plaiul Fagului Reserve, including the lakes.

Acknowledgements. The study was performed under the project 20.80009.7007.02. The author would like to thank Martin Lemke for confirming the identification of the species. 


\section{Bibliography}

1. Andreev Alexei, Bezman-Moseiko O., Bondarenco A., Budzhak V., Cherevatov V., Chiornei I., Derjanschi V., Ghendov V., Jurminschi S., Izverskaia T., Mantorov O., Medvedenco D., Munteanu A., Redcozubov O., Romanciuc A., Rusciuc A., Rusciu V., Sîrodoev Gh., Şabanova G., Skilskyi I., Sotnikov V., Şuberneţki O., Talmaci I., Tişenkov A., Tişenkova V., Țurcan V. Registrul zonelor nucleu ale Rețelei Ecologice Naționale a Republicii Moldova. BIOTICA, 2012, 356 p.

2. Artobolevsky G. To the fauna of Odonata of Bessarabia. Materials to the knowledge of the fauna of South West Russia, 1917, 2, 58.

3. Bezvali V. Odonata de Besarabie. In: Buletinul Muzeului Naţional de Istorie Naturală din Chişinău, 1932, 4, 68-69.

4. Cartea Roşie a Republicii Moldova. Ed. III. Chişinău:"Ştiinţa", 2015, 492 p.

5. Dyatlova E., Dragonflies of Moldova: state of knowledge and personal observations. International Dragonfly Fund - Report, 2010, 25, 1-43.

6. Manci C. O., Popescu I. E. Fifty years later: the rediscovery of Leucorrhinia pectoralis (Odonata: Libellulidae) in Romania. Travaux du Muséum National d'Histoire Naturelle «Grigore Antipa», 2017, 59(2), 109-113.

7. Natura Rezervaţiei Plaiul Fagului. Chişinău, 2005, 431 p.

8. Гендов В.С., Держанский В.В., Журминский С.Д., Изверская Т .Д., Ионица О.В., Манторов О. Г., Романович Н.А., Рущук А.Д., Сыродоев Г .Н., Тищенков А.А., ТофанДорофеев Е.В., Цуркану В.Ф. Атлас редких видов флоры и фауны международного и национального значения в Рамсарском сайте "Нижний Днестр", Республика Молдова. Кишинёв: Экологическое общество "ВІОТІСА", 2021, 607 с.

9. https://ig.idsi.md/index.php?go=noutati_detalii\&n=2333\&new_language $=1$ (accesat 20.07.2021).

10. https://ukrbin.com/index.php?id=2391 (accesat 20.07.2021). 